\title{
Role of Phosphodiesterases in the Regulation of Endothelial Permeability In Vitro
}

\author{
N. Suttorp, ${ }^{\star}$ U. Weber, ${ }^{\star}$ T. Welsch, ${ }^{\star}$ and C. Schudt ${ }^{*}$ \\ * Department of Internal Medicine, Justus Liebig-University, W-6300 Giessen, Klinikstrasse 36, Germany; \\ and ${ }^{\ddagger}$ Department of Biochemistry, Byk Gulden Pharmaceuticals, W-7750 Konstanz, Germany
}

\begin{abstract}
Neutrophil-derived hydrogen peroxide $\left(\mathrm{H}_{2} \mathrm{O}_{2}\right)$ is believed to play an important role in the pathogenesis of vascular injury and pulmonary edema. $\mathrm{H}_{2} \mathrm{O}_{2}$ time- and dose-dependently increased the hydraulic conductivity and decreased the selectivity of an endothelial cell monolayer derived from porcine pulmonary arteries. Effects of $\mathrm{H}_{2} \mathrm{O}_{2}$ on endothelial permeability were completely inhibited by adenylate cyclase activation with $10^{-12}$ $M$ cholera toxin or $0.1 \mu M$ forskolin. $1^{-8} \mathrm{M}$ Sp-cAMPS, a cAMP-dependent protein kinase A agonist, was similarly effective. The phosphodiesterase (PDE) inhibitors motapizone $\left(10^{-4} \mathrm{M}\right)$, rolipram $\left(10^{-6} \mathrm{M}\right)$, and zardaverine $\left(10^{-8} \mathrm{M}\right)$, which specifically inhibit PDE-isoenzymes III, IV, and III/IV potently blocked $\mathrm{H}_{2} \mathrm{O}_{2}$-induced endothelial permeability when combined with $10^{-6} \mathrm{M}$ prostaglandin $\mathrm{E}_{1}$. Overall cellular cAMP content and inhibition of $\mathrm{H}_{2} \mathrm{O}_{2}$ effects on endothelial permeability were poorly correlated. $\mathrm{H}_{2} \mathrm{O}_{2}$ exposure resulted in a rapid and substantial decrease in endothelial cAMP content. The analysis of the PDE isoenzyme spectrum showed high activities of isoenzymes II, III, and IV in porcine pulmonary endothelial cells. The data suggest that adenylate cyclase activation / PDE inhibition is a powerful approach to block $\mathrm{H}_{2} \mathrm{O}_{2}$-induced increase in endothelial permeability. This concept appears especially valuable when endothelial PDE isoenzyme pattern and PDE inhibitor profile are matched optimally. ( $J$. Clin. Invest. 1993.91:1421-1428.) Key words: cultured pulmonary endothelial cells $\bullet$ hydraulic conductivity $\bullet$ albumin reflection coefficient $\bullet$ adenylate cyclase activation $\bullet$ phosphodiesterase isoenzymes
\end{abstract}

\section{Introduction}

The endothelium provides a major permeability barrier of the vessel wall. In the course of inflammation, polymorphonuclear leukocytes may damage endothelial cells resulting in an increased vascular permeability. Hydrogen peroxide $\left(\mathrm{H}_{2} \mathrm{O}_{2}\right)$ is an important polymorphonuclear leukocyte-derived mediator of endothelial cell injury (1-3). Intracellular events after $\mathrm{H}_{2} \mathrm{O}_{2}$ exposure are manyfold and include a drop in ATP, NADH, and glutathione levels, an increased hydrolysis of inositol phos-

Parts of this work will be included in the M.D. theses of U. Weber and T. Welsch.

Address correspondence Norbert Suttorp, M.D., Department of Internal Medicine, University of Giessen, Klinikstrasse 36, W-6300 Giessen, Germany.

Received for publication 4 March 1992 and in revised form $20 \mathrm{Au}$ gust 1992.

J. Clin. Invest.

(C) The American Society for Clinical Investigation, Inc.

$0021-9738 / 93 / 04 / 1421 / 08 \quad \$ 2.00$

Volume 91, April 1993, 1421-1428 pholipids, as well as an enhancement of the intracellular $\mathrm{Ca}^{2+}$ concentration (4-9). As a result endothelial permeability may increase, possibly caused by $\mathrm{Ca}^{2+}$-mediated endothelial cell contraction (10-12).

Studies using isolated lungs and endothelial cell monolayers grown on filter membranes have shown a protective effect of cAMP-increasing reagents on increased vascular permeability (13-19). Endothelial adenylate cyclase can be stimulated by $\beta$-receptor agonists or experimentally by cholera toxin or the diterpene forskolin (20). In addition, 3-isobutyl-1-methylxanthine, an unselective and weak inhibitor of phosphodiesterases (PDE), ${ }^{1}$ has been used frequently to increase cellular cAMP content (21).

Five PDE isoenzymes have been identified so far in mammalian tissue (22). The PDE classification is based on substrate specificity and regulation characteristics (22). Selective inhibitors are known for most of the PDE isoenzymes (PDE III selective motapizone, PDE IV selective rolipram, and PDE III/ IV dual selective zardaverine) (22-24). PDE isoenzyme pattern differs among tissues and cells. For endothelial cells, the expression of at least two PDE isoenzymes have been described $(25,26)$. The identification of class-specific PDE inhibitors probably will allow a more efficient intervention in different target tissues in many pathophysiological situations $(22,23)$.

In the present study, $\mathrm{H}_{2} \mathrm{O}_{2}$-induced alterations of endothelial cell monolayer permeability were examined. Using this well-characterized system, effects of isoenzyme specific PDE inhibitors were studied. In addition, the PDE isoenzyme pattern in pig pulmonary artery endothelial cells was analyzed and correlated to the functional studies.

\section{Methods}

Materials. Tissue culture plasticware was obtained from Becton-Dickinson (Heidelberg, Germany). Medium 199, FCS, HBSS, trypsinEDTA solution, Hepes, and antibiotics were from Gibco (Karlsruhe, Germany) Collagenase (type CLS II) was purchased from Worthington Biochemical Corp. (Freehold, NJ). $\mathrm{H}_{2} \mathrm{O}_{2}$ was from Merck (Darmstadt, Germany). Gelatin from porcine skin type I, cholera toxin, forskolin, $\mathrm{PGE}_{1}$, and catalase were purchased from Sigma Chemical Co., Munich, Germany). The two cyclic adenosine monophosphorothioates Sp-cAMPS and Rp-cAMPS were a gift of Sandoz Research Institute (East Hanover, NJ). 4-(3'-cyclopentyl-oxy-4'-methoxyphenyl)-2-pyrrolidone (rolipram) was kindly provided by Schering AG, (Berlin). 4,5-dihydro-6-(4-(1H-imidazol-1-yl)-2-thienyl)-5-methyl-3-(2H)-pyridazinone (motapizone) and 2-O-propoxyphenyl-8-azapurine-6-one (zaprinast) were kindly provided by Rhone-Poulenc Rorer GmbH (Cologne, Germany). 6-(difluormethoxy-3-methoxyphenyl)-3-(2H)-pyridazinone (zardaverine) was synthesized by Byk Gulden $\mathrm{GmbH}$ (Konstanz, Germany). ${ }^{3} \mathrm{H}_{2} \mathrm{O}(1 \mathrm{mCi} / \mathrm{g})$ and labeled cyclic nucleotides were obtained from New England Nuclear (Dreieich, Germany). Methyl- ${ }^{14} \mathrm{C}$-albumin $(0.026 \mathrm{mCi} / \mathrm{mg})$ and the

1. Abbreviations used in this paper: $\mathrm{LDH}$, lactate dehydrogenase; PDE, phosphodiesterases. 
${ }^{125}$ I-cAMP assay system were from Amersham Buchler (Braunschweig, Germany). Polycarbonate micropore filter membranes ( $25 \mathrm{~mm}$ diameter, $5 \mu \mathrm{m}$ pore size) were purchased from Nucleopore $\mathrm{GmbH}$ (Tübingen, Germany). All other chemicals used were analytical grade.

Botulinum C2 toxin was prepared and activated as reported previously (11). Staphylococcus aureus alpha toxin was purified as described by Bhakdi et al. (27).

Preparation of endothelial cells. Pulmonary artery endothelial cells were obtained from freshly slaughtered pigs by exposure to $0.1 \%$ collagenase for 12-15 min. Endothelial cells were isolated, characterized, maintained, and dispersed as previously described (28-30).

All studies performed (permeability, cAMP content, PDE activity, lactate dehydrogenase ( $\mathrm{LDH}$ ) release) were done on endothelial cells in their third passage. In addition, all parameters (except PDE activity) were determined on the same batch of cells. There were, however, differences with respect to matrix (cells on polycarbonate membranes, flasks, or well plates).

Endothelial cell monolayers were grown on polycarbonate filter membranes that were first coated with gelatin, exposed to glutaraldehyde, and sterilized as described $(10,11)$. The coated filter membranes were placed in the bottom of a petri dish, about $2 \times 10^{6}$ cells were seeded on the filter in medium 199/10\% FCS and allowed to adhere for $3 \mathrm{~h}$. Additional $10 \mathrm{ml}$ of medium was then added to the petri dish. Thereafter, the monolayers were fed every other day and used $\sim 6 \mathrm{~d}$ after plating.

Analysis of endothelial permeability. A confluent filter membrane was mounted in a modified chemotaxis chamber. Hydraulic conductivity of cell monolayers was determined as follows: The upper and lower compartments were filled with HBSS supplemented with $0.25 \%$ albu$\mathrm{min}$. One port to the upper compartment is for substitution of filtrated volume and for application of pressure and one port is for the addition of reagents. The lower compartment of the system is part of a semiclosed perfusion system ( total vol $=10 \mathrm{ml}$ ). A roller pump provides a flow of $10 \mathrm{ml} / \mathrm{min}$. The circulating fluid drips into a $1-\mathrm{ml}$ capillary; the height of the fluid level in this capillary directly corresponds to the volume filtrated through the cell monolayer. A filtrated volume of $10 \mu \mathrm{l}$ can reliably be measured. The entire system is kept at $37^{\circ} \mathrm{C}$ by a heated water bath. A hydrostatic pressure of $10 \mathrm{~cm} \mathrm{H} \mathrm{H}_{2} \mathrm{O}$ was continuously applied to the upper side of the cell monolayer. The filtration rate across the endothelial monolayer was continuously determined $(10,11)$.

Albumin reflection coefficient. For calculation of this parameter 100 $\mathrm{nCi}^{3} \mathrm{H}_{2} \mathrm{O}$ and $100 \mathrm{nCi}^{14} \mathrm{C}$-albumin were added to the upper compartment. The amount of ${ }^{3} \mathrm{H}_{2} \mathrm{O}$ and ${ }^{14} \mathrm{C}$-albumin in the lower compartment was continuously measured in a radioactivity monitor (Ramona LS-5; Raytest, Heidelberg, Germany) consisting of a flow through cell, a splitter/mixer, and an IBM-PC for data calculation (for details, see references 10 and 11). The albumin reflection coefficient (RC) of the endothelial cell monolayer was calculated every $5 \mathrm{~min}$ on the basis of ${ }^{3} \mathrm{H}_{2} \mathrm{O}$ and ${ }^{14} \mathrm{C}$-albumin in the upper and lower compartments of the filter system according to the formula: $R C=1-(A / B \times D / C)$, as outlined $(10,11)$. $A$ and $C$ are the differences (in cpm/ ml) of ${ }^{14} \mathrm{C}$-albumin and ${ }^{3} \mathrm{H}_{2} \mathrm{O}$, respectively, in the lower compartment of the system between time points $x$ and $x+5$ min, multiplied by the volume of the lower compartment. $B$ and $D$ are the sums (in cpm/ $\mathrm{min}$ ) of ${ }^{14} \mathrm{C}$-albumin and ${ }^{3} \mathrm{H}_{2} \mathrm{O}$, respectively, in the upper compartment at time points $x$ and $x+5 \mathrm{~min}$, divided by 2 . Calculation of $A / B(C / D)$ yields the albumin (water) clearance.

Overall cellular cAMP content was measured by a radioimmunoassay using a commercially available ${ }^{125}$ I assay system as described (24). Endothelials cells were grown in 24-well plates to confluence in complete medium with $20 \%$ FCS (about 250,000 cells/well). At the end of the experiments, the medium was aspirated and cells were washed twice with HBSS; buffer contained $0.5 \mathrm{mM}$ isobutyl-methylxanthine to inhibit phosphodiesterase and prevent subsequent cAMP breakdown during cell solubilization and sample processing. Cells were extracted twice with $500 \mu \mathrm{l}$ ice-cold $65 \%$ ethanol. Extracts were evaporated under a stream of nitrogen at $60^{\circ} \mathrm{C}$ and dissolved in assay buffer. An aliquot of the extracts and of the standards were acetylated by addition of acetic anhydride and triethylamine (1:2) to enhance the sensitivity of cAMP detection.

Release of LDH was used as a marker of cytotoxicity. Endothelial cell monolayers grown on the polycarbonate filter membranes were exposed to $1 \mathrm{mM} \mathrm{H}_{2} \mathrm{O}_{2}$ for $90 \mathrm{~min}$. The medium was removed and centrifuged with $8,000 \mathrm{~g}$ for $2 \mathrm{~min}$. LDH activity in the supernatant was determined by the colorimetric measurement of the reduction of sodium pyruvate in the presence of NADH as described (11). Enzyme release was expressed as the percentage of total enzyme activity liberated from endothelial cells in the presence of $100 \mu \mathrm{g} / \mathrm{ml}$ mellitin $(10,11)$.

Assay of phosphodiesterase. PDE activity was determined as described (23). A standard reaction mixture containing $40 \mathrm{mM}$ Tris ( $\mathrm{pH}$ $8.0), 5 \mathrm{mM} \mathrm{MgCl} 2,0.1 \mathrm{mg} / \mathrm{ml} \mathrm{BSA}$ and $0.5 \mu \mathrm{M}$ cyclic nucleotide $/{ }^{3} \mathrm{H}$ labeled cyclic nucleotide (about $50,000 \mathrm{cpm}$ ) was used in a total volume of $200 \mu$ l. The reaction was initiated by addition of the enzyme solution $(5-20 \mu \mathrm{g})$ and was carried out at $37^{\circ} \mathrm{C}$ for $10 \mathrm{~min}$. The reaction was stopped by addition of $50 \mu 10.2 \mathrm{M} \mathrm{HCl}$ followed by cooling on ice for $10 \mathrm{~min}$. Crotalus atrox snake venom $(50 \mu \mathrm{l} ; 1 \mathrm{mg} / \mathrm{ml}$ in $0.2 \mathrm{M}$ Tris, $\mathrm{pH} \mathrm{8.0)}$ was added. After $10 \mathrm{~min}$ incubation at $37^{\circ} \mathrm{C}$ the reaction was stopped on ice. A $0.2 \mathrm{ml}$ aliquot of the assay volume was applied to a small column (Econo; Bio-Rad Labs, Richmond, CA) containing 1 $\mathrm{ml}$ QAE-A25-sephadex followed by $2 \mathrm{ml}$ of $30 \mathrm{mM}$ ammonium formate ( $\mathrm{pH} 6.0$ ). The effluent was collected directly in scintillation vials.

Determination of PDE isoenzyme activities. Activities of the five PDE isoenzymes were evaluated directly in the supernatant and particulate fraction of cell homogenates derived from (with respect to cAMP) determinations and permeability studies, passage-matched endothelial cultures. $3.5 \times 10^{7}$ endothelial cells grown in flasks were washed and scraped into buffer A ( $20 \mathrm{mM}$ Bis-Tris, $5 \mathrm{mM}$ dithioerythritol, $2 \mathrm{mM}$ EGTA, and $50 \mathrm{mM}$ sodium acetate, $50 \mu \mathrm{M}$ phenyl-methylsulfonylfluoride, $5 \mu \mathrm{M}$ pepstatin, $40 \mu \mathrm{M}$ leupeptin, $20 \mu \mathrm{M}$ aprotinin, and $2 \mathrm{mM}$ benzamidine). Cells were disrupted by sonication (Branson Sonifier; Branson Instruments, Danburg, CT) three times for $10 \mathrm{~s}$ on ice at a power output of $70 \mathrm{~W}$ and the homogenate was centrifuged at 100,000 $g$ for $20 \mathrm{~min}$ at $4^{\circ} \mathrm{C}$. Supernatant and resuspended pellet (i.e., cytosolic and particulate fractions) were used immediately for PDE assay.

Contributions made by PDE III and IV to total PDE activity were determined by quantifying the inhibition of PDE activity in the presence of $1 \mu \mathrm{M}$ motapizone and $10 \mu \mathrm{M}$ rolipram, respectively. PDE I and PDE II fractions of total PDE activity were calculated from the activity increase induced by $50 \mu \mathrm{M}$ calcium chloride/15 $\mathrm{nM}$ calmodulin or 5 $\mu \mathrm{M}$ cGMP, respectively (simultaneous presence of $1 \mu \mathrm{M}$ motapizone and $10 \mu \mathrm{M}$ rolipram). PDE $\mathrm{V}$ fraction was determined from inhibition induced by $10 \mu \mathrm{M}$ zaprinast in the presence of $0.5 \mu \mathrm{M}$ cGMP as substrate. The concentrations of the selective inhibitors that were used blocked $>95 \%$ of the activity of the respective PDE isoenzyme.

Experimental protocol. "Sealed" endothelial cell monolayers were used in this study; i.e., monolayers which showed a final hydraulic conductivity of $<5-10 \cdot 10^{-6} \mathrm{~cm} \cdot \mathrm{s}^{-1} \cdot \mathrm{cm} \mathrm{H}_{2} \mathrm{O}^{-1}$ and an albumin $\mathrm{RC}$ $>0.65$ in the presence of a hydrostatic pressure of $10 \mathrm{~cm} \mathrm{H}_{2} \mathrm{O}$. In all experiments, $\mathrm{H}_{2} \mathrm{O}_{2}$ was added as a bolus into the upper compartment at time 0 and then was infused continuously. Inhibitors were added as a bolus $15 \mathrm{~min}$ before $\mathrm{H}_{2} \mathrm{O}_{2}$ and were then infused continuously into the upper compartment. Possible effects of all reagents added on $\mathrm{H}_{2} \mathrm{O}_{2}$ concentration were checked and excluded spectrophotometrically at $230 \mathrm{nmM}$ according to Beers and Sizer (31).

Statistical methods. Depending on the number of groups (A) and the number of different time points studied (B), data of Figs. 1-5 and Table I were analyzed by an A $\times$ B ANOVA. The data in Table III were analyzed using a one-way ANOVA. Main effects were then compared by an F probability test (32). Otherwise, data were analyzed by Student's $t$ test for unpaired samples. $P<0.05$ was considered significant.

\section{Results}

Effect of $\mathrm{H}_{2} \mathrm{O}_{2}$ on endothelial permeability. Resting endothelial cell monolayers showed a hydraulic conductivity of $2 \times 10^{-6}$ $\times \mathrm{s}^{-1} \times \mathrm{cm} \mathrm{H}_{2} \mathrm{O}^{-1}$ and an albumin $\mathrm{RC}$ of $0.70-0.75 . \mathrm{H}_{2} \mathrm{O}_{2}$ 
increased the hydraulic conductivity of a sealed endothelial cell monolayer dose $(0.05-5 \mathrm{mM})$ and time dependently (15-75 min). This $\mathrm{H}_{2} \mathrm{O}_{2}$ effect was abolished in the presence of catalase, an enzyme that metabolizes $\mathrm{H}_{2} \mathrm{O}_{2}$ to $\mathrm{O}_{2}$ and $\mathrm{H}_{2} \mathrm{O}$ (Fig. 1). Addition of $\mathrm{H}_{2} \mathrm{O}_{2}$ resulted also in a dramatic decrease in the albumin reflecting properties of the endothelial cell monolayer (Fig. 2). $1 \mathrm{mM} \mathrm{H}_{2} \mathrm{O}_{2}$ was chosen for all subsequent studies using different inhibitors.

Effects of cAMP-modifying reagents. Preincubation of endothelial cell monolayers for $60 \mathrm{~min}$ with $1 \mathrm{pM}$ cholera toxin or more made them resistant to a subsequent $\mathrm{H}_{2} \mathrm{O}_{2}$ exposure while $10^{-13} \mathrm{M}$ cholera toxin only slightly reduced $\mathrm{H}_{2} \mathrm{O}_{2}$-induced increase in endothelial permeability (Table I). 10-50 $\mathrm{nM}$ forskolin reduced and $0.1-1 \mu \mathrm{m}$ forskolin inhibited the effect of $\mathrm{H}_{2} \mathrm{O}_{2}$ on endothelial permeability (Table I). These results clearly indicated that an activation of adenylate cyclase antagonizes the permeability increasing effect of $\mathrm{H}_{2} \mathrm{O}_{2}$.

$\mathrm{PGE}_{1}$ and isoproterenol, two receptor-operated adenylate cyclase activators, blocked the effects of $\mathrm{H}_{2} \mathrm{O}_{2}$ on endothelial permeability at $10^{-4} \mathrm{M}$ (not shown). $5 \mathrm{mM}$ of the membrane permeable cAMP analogue dibutyryl-cAMP were also inhibitory in this system (not shown). 10 nM Sp-cAMPS, a cAMPdependent protein kinase agonist (15), blocked $\mathrm{H}_{2} \mathrm{O}_{2}$-induced increase in endothelial permeability (Table I). Rp-cAMPS, a putative cAMP-dependent protein kinase antagonist (15), was used as a control to Sp-cAMPS. $100 \mathrm{nM}$ Rp-cAMPS were without effect in the experimental system used.

Effects of PDE inhibitors. Next, PDE III selective motapizone, PDE IV selective rolipram, and PDE III/IV dual selective zardaverine were tested (22-24). The effects of $\mathrm{H}_{2} \mathrm{O}_{2}$ on endothelial permeability were completely inhibited by $10^{-4} \mathrm{M}$ zardaverine, rolipram, and motapizone (Fig. 3). A 50\% reduction of the hydraulic conductivity was noted by $10^{-5} \mathrm{M}$ zardaverine, $10^{-6} \mathrm{M}$ rolipram, and $10^{-5} \mathrm{M}$ motapizone.

The combination of a receptor-operated stimulus $\left(\mathrm{PGE}_{1}\right)$ and a PDE inhibitor was tested. When $1 \mu \mathrm{M} \mathrm{PGE}_{1}$, which, per se, was slightly inhibitory was used, a complete inhibition of the $\mathrm{H}_{2} \mathrm{O}_{2}$-induced increase in hydraulic conductivity was noted

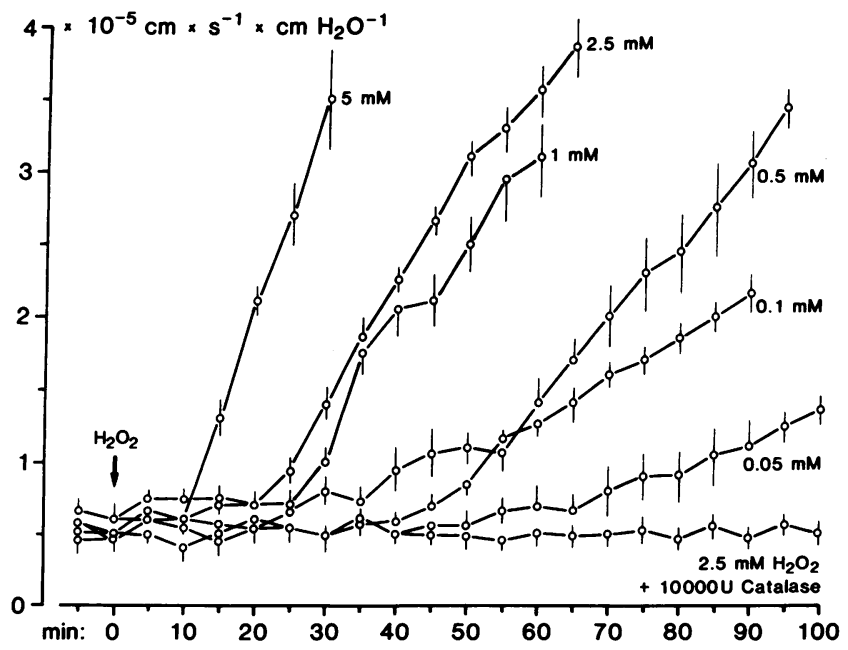

Figure 1. Hydrogen peroxide dose dependently $(0.05-5 \mathrm{mM})$ increased the permeability of endothelial monolayers. Permeability is indicated as hydraulic conductivity $\left(\mathrm{cm} \cdot \mathrm{s}^{-1} \cdot \mathrm{cm} \mathrm{H}_{2} \mathrm{O}^{-1}\right) \cdot \mathrm{H}_{2} \mathrm{O}_{2}$ was added as a bolus at $0 \mathrm{~min}$ and then infused continuously. Catalase that detoxifies $\mathrm{H}_{2} \mathrm{O}_{2}$ was added one minute before $\mathrm{H}_{2} \mathrm{O}_{2}$. Data presented are mean $\pm \mathrm{SE}$ of six separate studies.

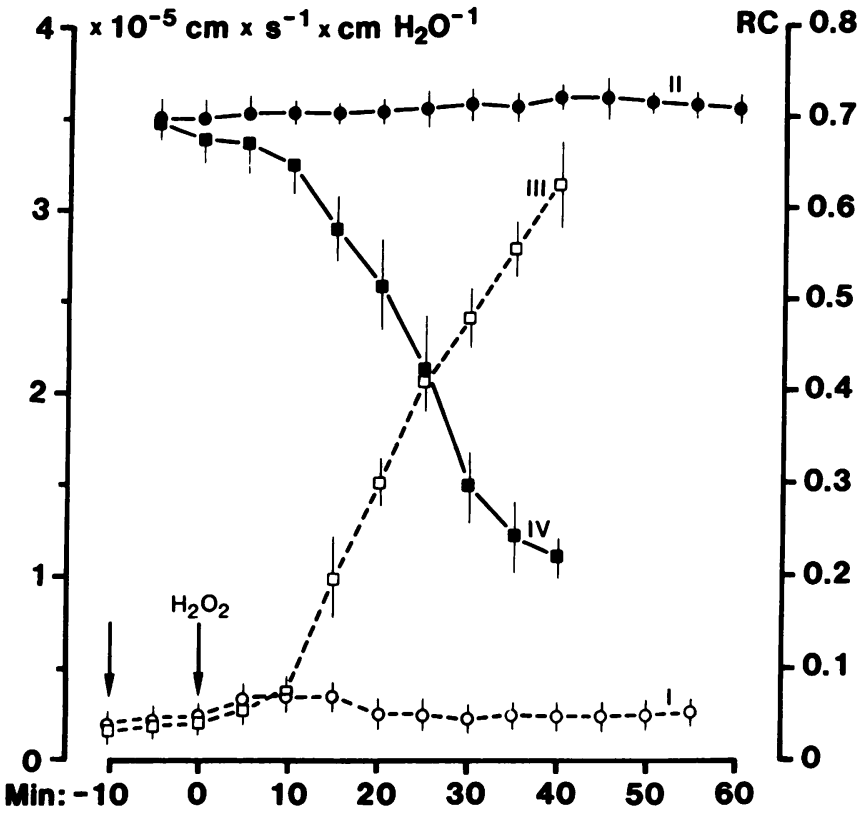

Figure 2. Resting endothelial monolayer had a hydraulic conductivity of $2 \times 10^{-6} \mathrm{~cm} \cdot \mathrm{s}^{-1} \cdot \mathrm{cm} \mathrm{H}_{2} \mathrm{O}^{-1}$ and an albumin reflection coefficient $(R C)$ of $0.7 . \mathrm{H}_{2} \mathrm{O}_{2}(1 \mathrm{mM})$ increased Hydrolyzing Capacity $(I I I)$ and decreased $\mathrm{RC}(I V) \cdot 10^{-6} \mathrm{M} \mathrm{PGE}_{1}$ plus $10^{-7} \mathrm{M}$ zardaverine blocked the effects of $\mathrm{H}_{2} \mathrm{O}_{2}$ on Hydrolyzing Capacity $(I)$ and RC $(I I)$. Data presented are mean $\pm \mathrm{SE}$ of four separate experiments.

in the presence of $10^{-8} \mathrm{M}$ zardaverine, $10^{-6} \mathrm{M}$ rolipram, or $10^{-4} \mathrm{M}$ motapizone (Fig. 4). Thus, $\mathrm{PGE}_{1}$ increased the effectiveness of zardaverine by a factor of 10,000 and of rolipram by a factor of 100 , while the effectiveness of motapizone remained unchanged. When $10^{-7} \mathrm{M} \mathrm{PGE}_{1}$ was used zardaverine was completely inhibitory at $10^{-7} \mathrm{M}$ (instead of $10^{-8} \mathrm{M}$ ) (data not shown).

The combination of $10^{-7} \mathrm{M}$ zardaverine and $10^{-6} \mathrm{M} \mathrm{PGE}_{1}$ prevented the $\mathrm{H}_{2} \mathrm{O}_{2}$-induced increase in hydraulic conductivity (Fig. 4 and Fig. 2, line 1) and, in addition, the $\mathrm{H}_{2} \mathrm{O}_{2}$-induced decrease in the albumin reflection coefficient (Fig. 2, line 2).

An increased permeability was noted at low concentrations of rolipram $\left(10^{-7} \mathrm{M}\right)$, zardaverine $\left(10^{-6} \mathrm{M}\right)$, or zardaverine $\left(10^{-9} \mathrm{M}\right) / \mathrm{PGE}_{1}$. This phenomenon may be related to the known protein kinase $A$ induced phosphorylation and activation of PDE III $(33,34)$; in the presence of low concentrations of a PDE IV or PDE III/IV inhibitor the activity of the CAMPdependent protein kinase will increase. PDE III, one target of this reaction, will increase its activity, thereby enhancing overall endothelial cAMP hydrolyzing capacity. Thus, it is conceivable that over a narrow concentration range of PDE-inhibitors cAMP decreases and permeability increases "paradoxically."

Zardaverine plus $\mathrm{PGE}_{1}\left(10^{-6} \mathrm{M}\right.$, each) were effective only when added 5 or $2.5 \mathrm{~min}$ before $\mathrm{H}_{2} \mathrm{O}_{2}$ addition (Fig. 5). A slight reduction in $\mathrm{H}_{2} \mathrm{O}_{2}$-induced endothelial permeability was noted when $\mathrm{H}_{2} \mathrm{O}_{2}$ and treatment $\left(10^{-6} \mathrm{M}\right.$ zardaverine and $10^{-6}$ M PGE ${ }_{1}$ ) were added simultaneously ( Fig. 5, line 3). No "therapeutic" intervention was possible after $\mathrm{H}_{2} \mathrm{O}_{2}$ addition.

An increase in endothelial permeability provoked by 10 $\mu \mathrm{g} / \mathrm{ml}$ S. aureus alpha toxin, a transmembrane channel-forming protein (27), or by $100 \mathrm{ng} / \mathrm{ml}$ botulinum C2 toxin, an inhibitor of actin polymerization (11), was not blocked by rolipram at a concentration that reduced $\mathrm{H}_{2} \mathrm{O}_{2}$-induced increases in hydraulic conductivity (data not shown). 


\begin{tabular}{|c|c|c|c|c|}
\hline \multirow{2}{*}{$\begin{array}{c}\text { Reagents } \\
\text { added }\end{array}$} & \multicolumn{4}{|c|}{ Time } \\
\hline & 0 & 20 & 40 & 60 \\
\hline & \multicolumn{4}{|c|}{$\min$} \\
\hline No additions & $0.2 \pm 0.1$ & $0.3 \pm 0.1$ & $0.2 \pm 0.1$ & $0.2 \pm 0.1$ \\
\hline $\mathrm{H}_{2} \mathrm{O}_{2}(1 \mathrm{mM})$ & $0.8 \pm 0.2$ & $2.3 \pm 0.4$ & $4.6 \pm 0.5$ & $6.0 \pm 0.7$ \\
\hline $\mathrm{H}_{2} \mathrm{O}_{2}+\mathrm{CHT} 0.1 \mathrm{pM}$ & $0.6 \pm 0.2$ & $1.3 \pm 0.3$ & $3.6 \pm 0.7$ & $5.1 \pm 0.6$ \\
\hline $\mathrm{H}_{2} \mathrm{O}_{2}+\mathrm{CHT} 1.0 \mathrm{pM}^{*}$ & $0.5 \pm 0.1$ & $0.7 \pm 0.2$ & $0.7 \pm 0.2$ & $0.8 \pm 0.2$ \\
\hline $\mathrm{H}_{2} \mathrm{O}_{2}+\mathrm{CHT} 10.0 \mathrm{pM}^{*}$ & $0.4 \pm 0.1$ & $0.3 \pm 0.2$ & $0.3 \pm 0.2$ & $0.2 \pm 0.1$ \\
\hline $\mathrm{H}_{2} \mathrm{O}_{2}(1 \mathrm{mM})$ & $0.8 \pm 0.3$ & $1.7 \pm 0.3$ & $3.8 \pm 0.4$ & $5.8 \pm 0.4$ \\
\hline $\mathrm{H}_{2} \mathrm{O}_{2}+$ FSK $10 \mathrm{nM}^{*}$ & $0.7 \pm 0.1$ & $1.7 \pm 0.2$ & $2.0 \pm 0.3$ & $4.1 \pm 0.7$ \\
\hline $\mathrm{H}_{2} \mathrm{O}_{2}+\mathrm{FSK} 50 \mathrm{nM}^{*}$ & $0.6 \pm 0.1$ & $1.3 \pm 0.2$ & $1.5 \pm 0.3$ & $1.4 \pm 0.4$ \\
\hline $\mathrm{H}_{2} \mathrm{O}_{2}+\mathrm{FSK} 100 \mathrm{nM}^{*}$ & $0.5 \pm 0.1$ & $0.7 \pm 0.2$ & $0.7 \pm 0.2$ & $0.7 \pm 0.2$ \\
\hline $\mathrm{H}_{2} \mathrm{O}_{2}+\mathrm{FSK} 1.0 \mu \mathrm{M}^{*}$ & $0.4 \pm 0.1$ & $0.4 \pm 0.1$ & $0.4 \pm 0.1$ & $0.5 \pm 0.2$ \\
\hline $\mathrm{H}_{2} \mathrm{O}_{2}(1 \mathrm{mM})$ & $0.8 \pm 0.2$ & $1.7 \pm 0.4$ & $3.8 \pm 0.3$ & $6.0 \pm 0.4$ \\
\hline $\mathrm{H}_{2} \mathrm{O}_{2}+\mathrm{Sp}-\mathrm{cA} 1 \mathrm{nM}$ & $0.4 \pm 0.1$ & $0.8 \pm 0.3$ & $3.9 \pm 0.5$ & $6.1 \pm 0.8$ \\
\hline $\mathrm{H}_{2} \mathrm{O}_{2}+\mathrm{Sp}-\mathrm{cA} 5 \mathrm{nM}^{*}$ & $0.7 \pm 0.1$ & $1.5 \pm 0.3$ & $2.7 \pm 0.3$ & $3.0 \pm 0.8$ \\
\hline $\mathrm{H}_{2} \mathrm{O}_{2}+\mathrm{Sp}-\mathrm{cA} 10 \mathrm{nM}^{*}$ & $0.4 \pm 0.1$ & $0.5 \pm 0.1$ & $0.8 \pm 0.2$ & $1.0 \pm 0.3$ \\
\hline $\mathrm{H}_{2} \mathrm{O}_{2}+\mathrm{Sp}-\mathrm{cA} 100 \mathrm{nM}^{*}$ & $0.2 \pm 0.1$ & $0.2 \pm 0.2$ & $0.4 \pm 0.1$ & $0.3 \pm 0.1$ \\
\hline $\mathrm{H}_{2} \mathrm{O}_{2}+\mathrm{Rp}-\mathrm{cA} 100 \mathrm{nM}$ & $0.6 \pm 0.1$ & $1.2 \pm 0.3$ & $2.6 \pm 0.4$ & $5.5 \pm 0.4$ \\
\hline
\end{tabular}

Data represented are hydraulic conductivities $\left(10^{-5} \mathrm{~cm} \cdot \mathrm{s}^{-1} \cdot \mathrm{cm} \mathrm{H} \mathrm{H}_{2}^{-1}\right)$. Cells were preincubated with different reagents for $15 \mathrm{~min}(60 \mathrm{~min}$ for cholera toxin). ${ }^{*}$ Indicates significant difference of this group to cells treated with $\mathrm{H}_{2} \mathrm{O}_{2}$ alone.

Next, we examined the effect of adenylate cyclase activation/PDE-inhibition on endothelial cytolysis: LDH-release of control cells ( $\mathrm{no} \mathrm{H}_{2} \mathrm{O}_{2}, 0.1 \mu \mathrm{M}$ forskolin alone, $1 \mu \mathrm{M}$ PGE $1 / 1$ $\mu \mathrm{M}$ zardaverine alone) was $<5 \%$ of total cellular $\mathrm{LDH}$ at 1,3 , and $6 \mathrm{~h}$. $\mathrm{LDH}$ release in the presence of $1 \mathrm{mM} \mathrm{H}_{2} \mathrm{O}_{2}$ amounted to $4 \%, 63 \%$, and $95 \%$ at 1,3 , and $6 \mathrm{~h}$. $\mathrm{LDH}$ data in the $\mathrm{H}_{2} \mathrm{O}_{2}$ $+0.1 \mu \mathrm{M}$ forskolin group were $3 \%, 31 \%$, and $91 \%$; $\mathrm{LDH}$ data in the $\mathrm{H}_{2} \mathrm{O}_{2}+1 \mu \mathrm{M}$ PGE1 / $1 \mu \mathrm{M}$ zardaverine group were $3 \%$,

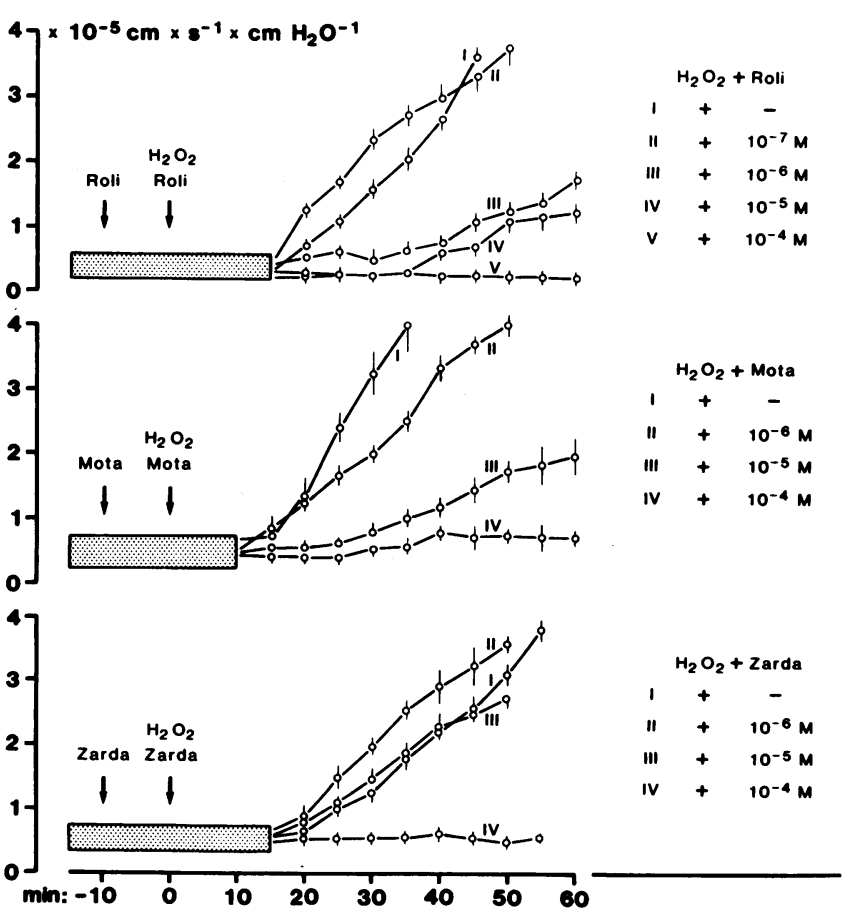

Figure 3. Modification of $\mathrm{H}_{2} \mathrm{O}_{2}$-induced increase in endothelial permeability by reagents that selectively inhibit different PDE isoenzymes. Rolipram (PDE IV), motapizone (PDE III), and zardaverine (PDE III/IV) were used at $10^{-4}-10^{-7} \mathrm{M}$. All PDE inhibitors blocked $\mathrm{H}_{2} \mathrm{O}_{2}$ effects at $10^{-4} \mathrm{M}$. Data presented are mean $\pm \mathrm{SE}$ of at least four separate experiments.

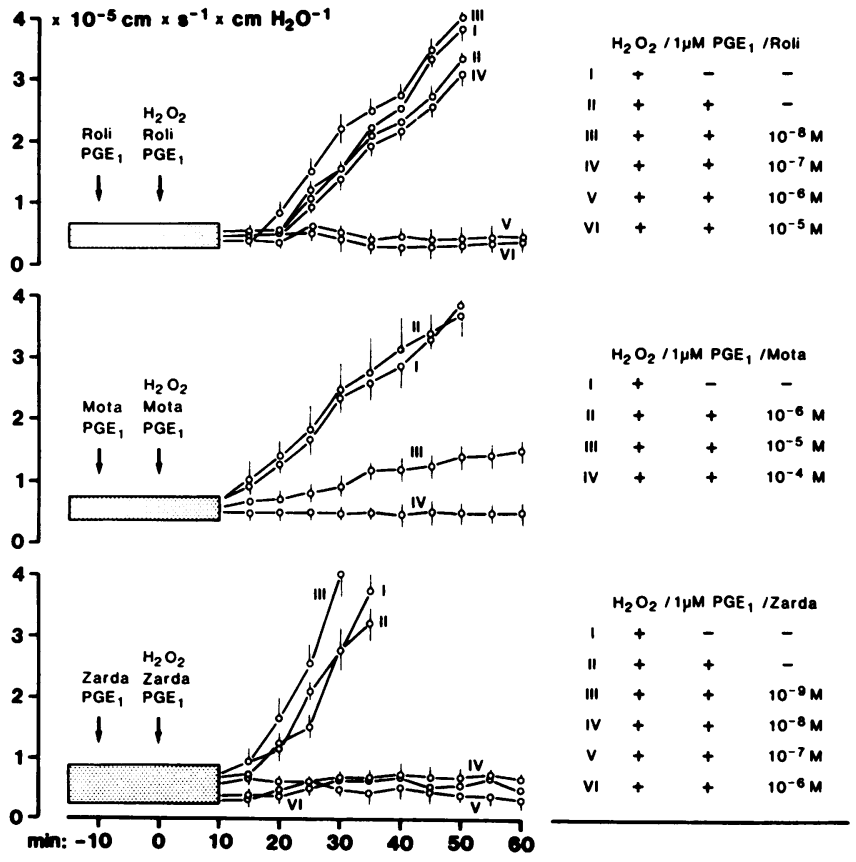

Figure 4. Simultaneous adenylate cyclase activation and PDE inhibition potently blocked $\mathrm{H}_{2} \mathrm{O}_{2}$-induced increase in endothelial permeability. Cell monolayers were incubated with $10^{-6} \mathrm{M} \mathrm{PGE}_{1}$ plus one of the PDE inhibitors. $10^{-6} \mathrm{M} \mathrm{PGE}_{1}$ alone only had a small effect in this system. In the presence of $\mathrm{PGE}_{1}, 10^{-8} \mathrm{M}$ zardaverine, $10^{-6} \mathrm{M}$ rolipram, or $10^{-4} \mathrm{M}$ motapizone completely blocked $\mathrm{H}_{2} \mathrm{O}_{2}$-related enhanced endothelial permeability. Data presented are mean $\pm \mathrm{SE}$ of at least four separate experiments. 


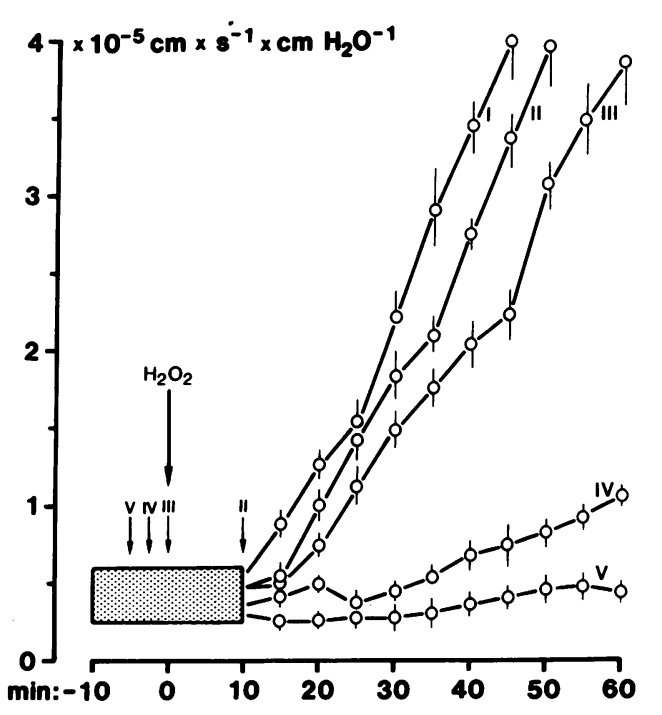

Figure 5. Pretreatment versus posttreatment: $\mathrm{PGE}_{1}$ and rolipram $\left(10^{-6} \mathrm{M}\right.$ each $)$ were added to the endothelial cell monolayer $5 \mathrm{~min}$ before $(V), 2,5 \mathrm{~min}$ before $(I V)$, simultaneously with $(I I I)$, or 10 min after $(I I)$ addition of $1 \mathrm{mM} \mathrm{H}_{2} \mathrm{O}_{2}\left(I=\mathrm{H}_{2} \mathrm{O}_{2}\right.$ alone). Simultaneous addition of stimulus and "therapy" slightly reduced $\mathrm{H}_{2} \mathrm{O}_{2}$-induced enhanced endothelial permeability. Pretreatment was very effective, posttreatment almost without effect in this system. Data presented are mean $\pm S E$ of at least three separate experiments.

$13 \%$, and $96 \%$ (SE of LDH data always $<10 \%, n=2$ ). Thus, adenylate cyclase activation/PDE-inhibition appears to delay (for 1-2 h) but does not prevent $\mathrm{H}_{2} \mathrm{O}_{2}$-induced endothelial cytolysis.

Endothelial cAMP content. Zardaverine, rolipram, and motapizone $\left(10^{-4} \mathrm{M}\right)$ did not increase endothelial cAMP content significantly. $1 \mu \mathrm{M} \mathrm{PGE}_{1}$ combined with $100 \mu \mathrm{M}$ of the PDE inhibitors tested nearly doubled endothelial cAMP ( Table II). At $1 \mu \mathrm{M}$ PGE $_{1}$ plus low concentrations of PDE inhibitors $\left(\leq 10^{-6} \mathrm{M}\right)$ endothelial cAMP content remained unchanged (not shown). Thus, $\mathrm{PGE}_{1}$ plus $\mathrm{PDE}$ inhibitor reduced $\mathrm{H}_{2} \mathrm{O}_{2}$-related increases in endothelial permeability at concentrations which did not increase overall cellular cAMP. Forskolin $\left(10^{-6}-10^{-8} \mathrm{M}\right)$ and choleratoxin $\left(10^{-9}-10^{-12} \mathrm{M}\right)$ drastically increased endothelial cAMP concentration from 4.3 to 40 pmol $/ 10^{6}$ cells.

Exposure of endothelial cells to $\mathrm{H}_{2} \mathrm{O}_{2}$ resulted in a rapid decline of cAMP content, which was significant after 5 min (Table III). Within $10-15$ min, cAMP decreased by $>50 \%$. High endothelial cAMP content after preincubation with forskolin fell with similar kinetics after $\mathrm{H}_{2} \mathrm{O}_{2}$ exposure (Table III). Pretreatment of endothelial cells with $\mathrm{PGE}_{1}$ and zardaverine did also not slow down the $\mathrm{H}_{2} \mathrm{O}_{2}$ induced cAMP fall. The relative rate of cAMP fall was even increased in the cholera toxin / $\mathrm{H}_{2} \mathrm{O}_{2}$ group (Table III).

$P D E$ isoenzymes in porcine pulmonary endothelial cells. The PDE isoenzyme profile of porcine pulmonary artery endothelial cells was analyzed in cytosolic and particulate fractions of cell homogenates. Activity levels of each isoenzyme were quantitated using the selective inhibitors motapizone (PDE III), rolipram (PDE IV), zardaverine (PDE III + IV), zaprinast (PDE V), and the allosteric effectors CGMP (PDE II) and $\mathrm{Ca}^{2+} /$ calmodulin (PDE I).

Concentration inhibition curves by zardaverine were monophasic, whereas those of motapizone and rolipram were bipha-
Table II. cAMP Content of Pulmonary Artery Endothelial Cells after Incubation with Different $C A M P$-modifying Reagents

\begin{tabular}{lccr}
\hline \multicolumn{1}{c}{ Reagents added } & Time & cAMP & $n$ \\
\hline & min & pmol & \\
None & 10 & $4.35 \pm 0.6$ & 10 \\
Zardaverine $(100 \mu \mathrm{M})$ & 10 & $5.12 \pm 0.6$ & 5 \\
Motapizone $(100 \mu \mathrm{M})$ & 10 & $4.74 \pm 0.7$ & 4 \\
Rolipram $(100 \mu \mathrm{M})$ & 10 & $5.76 \pm 1.7$ & 4 \\
PGE $_{1}(1 \mu \mathrm{M})$ & 10 & $5.50 \pm 1.3$ & 6 \\
PGE $_{1}+$ zardaverine & & & \\
$\quad(1+100 \mu \mathrm{M})$ & 10 & $7.78 \pm 1.2^{*}$ & 8 \\
PGE $_{1}+$ motapizone & & & \\
$\quad(1+100 \mu \mathrm{M})$ & 10 & $8.51 \pm 2.2^{*}$ & 4 \\
PGE $1+$ rolipram & & & \\
$\quad(1+100 \mu \mathrm{M})$ & 10 & $7.33 \pm 2.4^{*}$ & 4 \\
Forskolin $(1 \mu \mathrm{M})$ & 10 & $33.28 \pm 2.5^{*}$ & 4 \\
Forskolin $(0.1 \mu \mathrm{M})$ & 10 & $33.60 \pm 5.2^{*}$ & 3 \\
Forskolin $(0.01 \mu \mathrm{M})$ & 10 & $14.40 \pm 3.0^{*}$ & 3 \\
Cholera toxin $(1 \mathrm{nM})$ & 60 & $39.36 \pm 1.8^{*}$ & 4 \\
Cholera toxin $(1 \mathrm{pM})$ & 60 & $12.80 \pm 1.9^{*}$ & 2 \\
Cholera toxin $(0.1 \mathrm{pM})$ & 60 & $6.72 \pm 1.4$ & 2 \\
& & &
\end{tabular}

Data given are pmol cAMP $/ 10^{6}$ cells, mean \pm SE. * Indicates significant difference to untreated cells $(P<0.05)$.

sic indicating the presence of PDE III and IV (Fig. 6). Two-site analysis of the data of the cytosolic fraction revealed an IC50 value for PDE III and IV of $9 \mathrm{nM}$ and $42 \mu \mathrm{M}$ ( $13 \mathrm{nM}$ and 65 $\mu \mathrm{M}$ in particulate fraction) for motapizone and of $83 \mu \mathrm{M}$ and $93 \mathrm{nM}(110 \mu \mathrm{M}$ and $110 \mathrm{nM}$ in particulate fraction) for rolipram, respectively (Fig. 6). IC50 for zardaverine was $0.3 \mu \mathrm{M}$ $(0.5 \mu \mathrm{M})$ in cytosolic (particulate) fraction (Fig. 6). Zaprinast

Table III. cAMP Content of Endothelial Cells Incubated with $\mathrm{H}_{2} \mathrm{O}_{2}$ and cAMP-modifying Reagents

\begin{tabular}{lccccc}
\hline & \multicolumn{5}{c}{ Time } \\
\cline { 2 - 6 } \multicolumn{1}{c}{ added } & 0 & 5 & 15 & 30 & 60 \\
\hline & & & $\min$ \\
& 4.9 & 3.3 & 2.2 & 1.7 & 1.2 \\
$\mathrm{H}_{2} \mathrm{O}_{2}(1 \mathrm{mM}) ; n=6$ & \pm 0.3 & 0.2 & 0.2 & 0.1 & 0.1 \\
& & 67 & 45 & 35 & 24 \\
Percent of initial & 38.4 & 23.7 & 12.8 & 5.1 & $\mathrm{ND}$ \\
$0.1 \mathrm{nM}$ cholera toxin for & \pm 1.9 & 1.0 & 1.9 & 1.4 & $\mathrm{ND}$ \\
60 min, then $\mathrm{H}_{2} \mathrm{O}_{2} ; n=3$ & & 62 & 33 & 13 & \\
Percent of initial & 19.8 & 14.1 & 11.4 & 5.3 & $\mathrm{ND}$ \\
$0.1 \mu \mathrm{M}$ forskolin for & \pm 0.9 & 0.9 & 0.4 & 2.4 & $\mathrm{ND}$ \\
5 min, then $\mathrm{H}_{2} \mathrm{O}_{2} ; n=2$ & & 71 & 58 & 27 & \\
Percent of initial & 6.0 & 4.2 & 2.5 & 1.4 & 1.1 \\
PGE 1 zardaverine $(1+100 \mu \mathrm{M})$ & \pm 0.6 & 0.5 & 0.4 & 0.2 & 0.1 \\
10 min, then $\mathrm{H}_{2} \mathrm{O}_{2} ; n=5$ & & 70 & 42 & 23 & 18 \\
Percent of initial & & & & \\
& & & & &
\end{tabular}

Data indicate a substantial fall of cAMP in endothelial cells exposed to $1 \mathrm{mM} \mathrm{H}_{2} \mathrm{O}_{2}$. The cAMP-drop is significant $(P<0.05)$ for all groups at $5 \mathrm{~min}$ and later. ND, not determined. Data presented are pmol cAMP $/ 10^{6}$ cells (mean $\pm \mathrm{SE}$ ). The relative rate of cAMP fall is significantly enhanced in the cholera toxin $/ \mathrm{H}_{2} \mathrm{O}_{2}$ group as compared to $\mathrm{H}_{2} \mathrm{O}_{2}$ alone. 


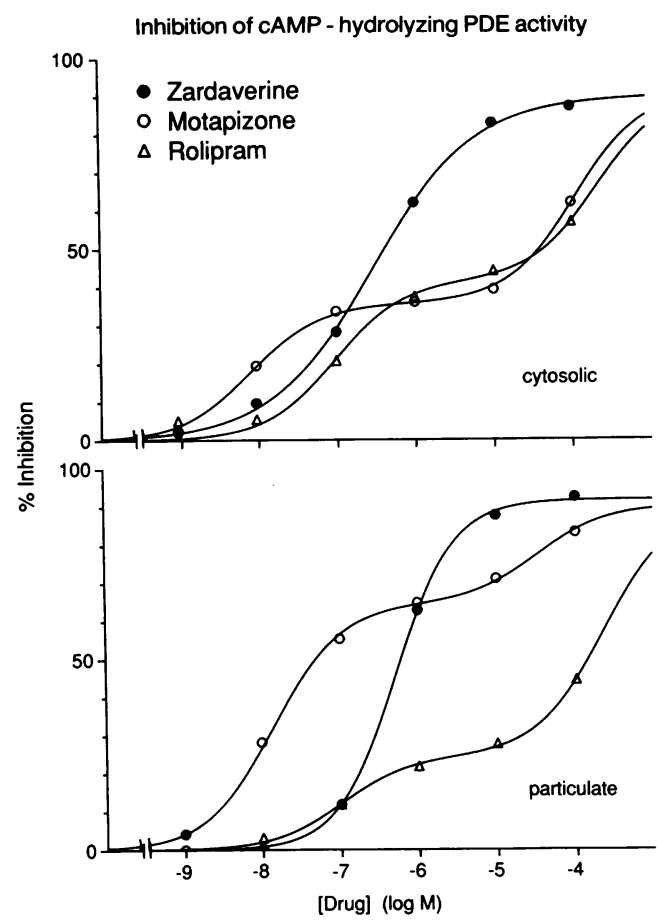

Figure 6. Analysis of PDE isoenzyme specific IC50 values for three different PDE inhibitors. Basal cAMP-hydrolyzing activity present in cytosolic and particulate fractions of endothelial cell lysates was assayed in the presence of $0.5 \mu \mathrm{M}$ cAMP as substrate. Inhibition of this activity was determined in the presence of increasing concentrations $\left(10^{-9}-10^{-4} \mathrm{M}\right)$ of zardaverine, motapizone, and rolipram. Curves were analysed by linear regression using a normal (for zardaverine) or a two-site fitting model (for motapizone and rolipram). See Results for calculated IC50 values. Data given are the result of one (out of three) representative experiment.

inhibited cGMP-selective PDE V with an IC50 of $0.3 \mu \mathrm{M}$ (not shown).

The contribution of each PDE isoenzyme made to overall basal cAMP-hydrolyzing activity $\left(3.7 \mathrm{nmol} / \mathrm{min}\right.$ per $10^{8}$ cells in the presence of $0.5 \mu \mathrm{M}$ substrate) was evaluated ( Table IV): PDE III and IV activities amounted to 1.6 and $1.4 \mathrm{nmol} / \mathrm{min}$ per $10^{8}$ cells. The combination of motapizone and rolipram inhibited the same fraction of basal activity as did zardaverine. Addition of $5 \mu \mathrm{M}$ cGMP to cell homogenates which contained rolipram and motapizone or zardaverine almost completely restored cAMP hydrolyzing activity indicating the presence of a cGMP-stimulated PDE that has been termed PDE II, as outlined in Beavo (22). PDE II was the isoenzyme with the highest activity $\left(2.3 \mathrm{nmol} / \mathrm{min}\right.$ per $10^{8}$ cells $)$. No selective PDE II inhibitors are known. $\mathrm{Ca}^{2+} /$ calmodulin did not stimulate and zaprinast, a selective PDE V inhibitor, did not reduce cAMP or cGMP hydrolyzing activity, suggesting that porcine pulmonary artery endothelial cells contained negible amounts of PDE subtypes I and V.

Fig. 7, which is based on data of Table IV, presents the distribution of PDE isoenzymes in porcine pulmonary artery endothelial cells. PDE III appeared to be located preferentially in the particulate compartment (74\%), whereas PDE IV was localized predominantly in the cytosol $(62 \%)$.

\section{Discussion}

Hydrogen peroxide $\left(\mathrm{H}_{2} \mathrm{O}_{2}\right)$ proved to be a potent mediator of enhanced endothelial permeability. It increased the porosity
Table IV. PDE Isoenzyme Activities in Cytosolic and Particulate Fractions of Endothelial Cell Homogenates

\begin{tabular}{lcc}
\hline & \multicolumn{2}{c}{ Activity } \\
\cline { 2 - 3 } \multicolumn{1}{c}{ Reagents added } & Cytosol & Particulate \\
\hline & \multicolumn{2}{c}{ cells } \\
& $1,719 \pm 77$ & $2,008 \pm 187$ \\
${ }^{3} \mathrm{H}$-cAMP & $825 \pm 386$ & $1,481 \pm 157$ \\
+ Rolipram $10 \mu \mathrm{M}$ & $1,296 \pm 130$ & $810 \pm 303$ \\
+ Motapizone $1 \mu \mathrm{M}$ & $312 \pm 95$ & $266 \pm 126$ \\
+ Rolipram + motapizone & $274 \pm 74$ & $291 \pm 186$ \\
+ Zardaverine $10 \mu \mathrm{M}$ & $1,940 \pm 103$ & $967 \pm 49$ \\
+ Rolipram + motapizone $+\mathrm{cGMP} 5 \mu \mathrm{M}^{2+}$ & $421 \pm 57$ & $186 \pm 34$ \\
+ Rolipram + motapizone $+\mathrm{Ca}^{2+} / \mathrm{CaM}$ & $923 \pm 278$ & $680 \pm 114$ \\
${ }^{3} \mathrm{H}-\mathrm{cGMP}$ & $884 \pm 231$ & $652 \pm 141$ \\
+ Zaprinast $10 \mu \mathrm{M}$ &
\end{tabular}

Basal PDE activity was assayed in the presence of $0.5 \mu \mathrm{M}$ cAMP (PDE I-IV) or CGMP (PDE V) as substrates. Activation by cGMP or $\mathrm{Ca}^{2+} /$ calmodulin (CaM) for quantitation of PDE II or I was done while PDE III and IV were blocked by the simultaneous presence of rolipram and motapizone. Data are mean $\pm \mathrm{SE}$ of three separate experiments.

and decreased the selectivity of an endothelial monolayer in a time- and dose-dependent manner. A similar oxidant-induced increase in albumin transfer across cultured endothelium was noted previously using xanthine or glucose oxidase as a source of reactive oxygen species $(35,36)$. Leukocyte-derived $\mathrm{H}_{2} \mathrm{O}_{2}$ in a subcytolytic concentration apparently can, besides alterations of endothelial permeability, induce a broad range of metabolic and functional alterations in endothelial cells including stimulation of arachidonate metabolism, DNA strand break formation, potassium-efflux, etc. (1-5).

In the present study, endothelial permeability was investigated in the presence of a well defined transendothelial pressure gradient $(10,11)$. Under these conditions, resting endothelial cell monolayers displayed a hydraulic conductivity of $2 \cdot 10^{-6} \mathrm{~cm} \cdot \mathrm{s}^{-1} \cdot \mathrm{cm} \mathrm{H}_{2} \mathrm{O}^{-1}$ and an albumin reflection coefficient of more than 0.7 ; i.e., the permeability characteristics of our in vitro system are close to the in situ situation.

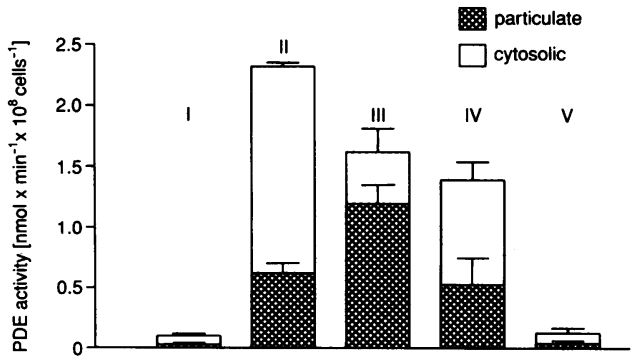

Figure 7. PDE isoenzyme activities in the cytosolic and particulate (criss-cross) fraction of porcine pulmonary artery endothelial cells were calculated from the inhibition induced by $1 \mu \mathrm{M}$ motapizone, 10 $\mu \mathrm{M}$ rolipram, and $10 \mu \mathrm{M}$ zaprinast. PDE III and IV were inhibited by the simultaneous presence of motapizone/rolipram to determine PDE II activity by activation with $5 \mu \mathrm{M}$ cGMP and PDE I activity by activation with $\mathrm{Ca}^{2+}$ /calmodulin. PDE isoenzyme activities were determined in the presence of $0.5 \mu \mathrm{M}$ cyclic nucleotides CAMP (PDE I-IV) and cGMP (PDE V). Data given are mean \pm SE of three separate experiments. 
Activation of adenylate cyclase suppressed $\mathrm{H}_{2} \mathrm{O}_{2}$-induced endothelial permeability. Cholera toxin and forskolin were effective at extremely low $\left(10^{-12}\right.$ and $\left.5 \times 10^{-8} \mathrm{M}\right)$ concentrations. The role of cAMP-dependent effects in regulating endothelial permeability was strengthened by studies with $\mathrm{PGE}_{1}$, a receptor-operated adenylate cyclase activator, and with $\mathrm{Sp}$ cAMPS, a cAMP-dependent protein kinase agonist. Our observations extend the demonstrated improvement of barrier properties in resting endothelial monolayers using norepinephrine, isoproterenol, or iloprost as cyclase activators (13-15).

PDE inhibition with motapizone, rolipram, or zardaverine blocked $\mathrm{H}_{2} \mathrm{O}_{2}$-related endothelial permeability at high concentrations $\left(10^{-4} \mathrm{M}\right)$, suggesting a low basal adenylate cyclase activity in these cells. As anticipated simultaneous adenylate cyclase activation / PDE-inhibition proved to be very potent. In the presence of $1 \mu \mathrm{M} \mathrm{PGE}_{1}$, the effectiveness of zardaverine and rolipram increased 10,000 and 100 times, respectively, whereas that of motapizone remained unchanged. Thus, a maximum effect was observed when both isoenzymes (PDE III and IV) were blocked, suggesting that PDE III and IV were actively hydrolysing cAMP under the conditions used, whereas PDE II seemed to be inactive.

An analysis of the PDE isoenzymes in porcine pulmonary artery endothelial cells showed high activities of PDE II, III, and IV. Two previous studies reported on the preparation and identification of PDE isoenzyme II and IV in bovine and porcine aortic endothelial cells $(25,26)$. Most of the cAMP hydrolytic activity was, similar to the present study, detected in the cytosolic fraction. The identification of PDE III in endothelial cells represents a novel observation. Three quarters of this isoenzyme was detected in the particulate fraction. The discrepancy to previous studies may relate to analytical differences. Our approach used is fast, circumvents much of the proteolytic degradation, and compares isoenzyme activities in the cytosolic and particulate compartment at $0.5 \mu \mathrm{M}$ as a substrate concentration.

Adenylate cyclase activation/PDE inhibition potently blocked $\mathrm{H}_{2} \mathrm{O}_{2}$-related enhanced endothelial permeability. This concept was especially effective when endothelial PDE isoenzyme pattern and profile of PDE inhibitors used were matched. While this concept appears clear, a straight correlation between endothelial cAMP-levels and protection against $\mathrm{H}_{2} \mathrm{O}_{2}$-related enhanced endothelial permeability was missing. Endothelial permeability was low and CAMP high in the presence of cholera toxin or forskolin. Zardaverine and $\mathrm{PGE}_{1}$, however, were protective at concentrations that did not increase detectable cAMP. This poor correlation is probably caused by determination of overall cellular cAMP content. Dependent on intracellular PDE distribution and on mode of adenylate cyclase activation high local subcellular cAMP peaks are likely to occur, as has already been demonstrated in microwave-fixed cells (37). These cAMP peaks probably are easily missed by global cAMP determinations in cell lysates.

Matters are further complicated by the fact that cAMP levels dropped in $\mathrm{H}_{2} \mathrm{O}_{2}$-exposed endothelial cells by $>50 \%$ within $15 \mathrm{~min}$, suggesting that an early cAMP peak is sufficient for providing protection against a $\mathrm{H}_{2} \mathrm{O}_{2}$ bolus. The observation of a $\mathrm{H}_{2} \mathrm{O}_{2}$-induced cAMP decrease made is new but not surprising, since a rapid ATP-fall is a well known phenomenon in $\mathrm{H}_{2} \mathrm{O}_{2}$-poisoned cells $(7,36,38,39)$. To our opinion, the low substrate concentration most likely explains the cAMP decrease in $\mathrm{H}_{2} \mathrm{O}_{2}$-exposed cells.

The mechanisms of the protection against $\mathrm{H}_{2} \mathrm{O}_{2}$-related en- hanced endothelial permeability by adenylate cyclase activation/PDE-inhibition are not clear; an answer relates to possible mechanisms of $\mathrm{H}_{2} \mathrm{O}_{2}$-induced cell injury. Exposure of endothelial cells to $\mathrm{H}_{2} \mathrm{O}_{2}$ results in a complex metabolic response including a drop in ATP and NADP, an activation of the glutathione cycle, an increased hydrolysis of inositol phospholipids, and an increase in intracellular free $\mathrm{Ca}^{2+}$ concentration (1-9, $35,36,38)$. This $\mathrm{Ca}^{2+}$ signal most likely induces a $\mathrm{Ca}^{2+}$-dependent actin/myosin-based endothelial cell contraction with subsequent interendothelial gap formation. Considerable evidence has been accumulated in support of this sequence $(10-12,40)$.

Adenylate cyclase activation/PDE inhibition with subsequent stimulation of protein kinase $A$ favors cell relaxation probably by decreasing the intracellular $\mathrm{Ca}^{2+}$ signal and by reducing myosin light chain kinase activity $(41,42)$. Failure of PDE inhibitors to block the effects of staphylococcal alpha toxin on endothelial permeability would be compatible with this notion because intracellular $\mathrm{Ca}^{2+}$ probably cannot be decreased in cells carrying a high number of toxin-induced membrane pores. On the other hand, Carson et al. (18) did not note a reduction of the histamine-induced $\mathrm{Ca}^{2+}$ signal in theophylline or forskolin exposed umbilical vein endothelial cells suggesting that cAMP-related $\mathrm{Ca}^{2+}$ handling may be different between cells. Additional studies examining intracellular $\mathrm{Ca}^{2+}$, protein kinase $\mathrm{C}$ activity, phospholipid hydrolysis, cytoskeleton, etc., will hopefully resolve the mechanisms of the therapeutic approach presented.

PMN-mediated vascular injury and oxidant-induced pulmonary edema are prominent features of the adult respiratory distress syndrome. Adenylate cyclase activation/PDE inhibition proved useful in blocking $\mathrm{H}_{2} \mathrm{O}_{2}$-related enhanced endothelial permeability in vitro. Further studies in more integrated systems are required to test this concept and to determine the optimal match between endothelial PDE isoenzyme pattern and PDE inhibitor profiles.

\section{Acknowledgments}

The technical assistance of S. Tannert-Otto, P. Röhrig, U. Richter, C. Auriga, and E. Boesebeck is greatly appreciated.

This work was supported by the Deutsche Forschungsgemeinschaft (Klinische Forschergruppe) and by the Justus-Liebig-University Award to N. Suttorp, who is also a recipient of a Schilling professorship.

\section{References}

1. Harlan, J. M., and K. S. Callahan. 1984. Role of hydrogen peroxide in the neutrophil-mediated release of prostacyclin from cultured endothelial cells. $J$. Clin. Invest. 74:442-448.

2. Suttorp, N., and L. M. Simon. 1982. Lung cell oxidant injury. Enhancement of polymorphonuclear leukocyte-mediated cytotoxicity in lung cells exposed to sustained in vitro hyperoxia. J. Clin. Invest. 70:342-350.

3. Ager, A., and J. L. Gordon. 1984. Differential effects of hydrogen peroxide on indices of endothelial cell function. J. Exp. Med. 159:592-603.

4. Spragg, R. G. 1991. DNA strand break formation following exposure of bovine pulmonary artery and aortic endothelial cells to reactive oxygen products. Am. J. Respir. Cell. Mol. Biol. 4:4-10.

5. Hinshaw, D. B., L. A. Sklar, B. Bohl, I. U. Schraufstätter, P. A. Hyslop M. W. Rossi, R. G. Spragg, and C. G. Cochrane. 1986. Cytoskeletal and morphologic impact of cellular oxidant injury. Am. J. Pathol. 123:454-464.

6. Schraufstätter, I. U., D. B. Hinshaw, P. A. Hyslop, R. G. Spragg, and C. G. Cochrane. 1985. Glutathione cycle activity and pyridine nucleotide levels in oxidant-induced injury of cells. J. Clin. Invest. 76:1131-1139.

7. Hyslop, P. A., D. B. Hinshaw, W. A. Halsey, I. U. Schraufstätter, R. D. Sauerheber, R. G. Spragg, J. H. Jackson, and C. G. Cochrane. 1988. Mechanisms of oxidant-mediated cell injury. J. Biol. Chem. 263:1665-1675.

8. Suttorp, N., W. Toepfer, and L. Roka. 1986. Antioxidant defense systems in endothelial cells: glutathione redox cycle versus catalase. Am. J. Physiol. 251:C671-C680. 
9. Shasby, D. M., M. Yorek, and S. S. Shasby. 1988. Exogenous oxidants initiate hydrolysis of endothelial cell inositol phospholipids. Blood. 72:491-499.

10. Suttorp, N., T. Hessz, W. Seeger, A. Wilke, R. Koob, F. Lutz, and D. Drenckhahn. 1988. Bacterial exotoxins and endothelial permeability for water and albumin. Am. J. Physiol. 255:C369-C376.

11. Suttorp, N., M. Polley, J. Seybold, H. Schnittler, W. Seeger, F. Grimminger, and K. Aktories. 1991. ADP-ribosylation of G-actin by botulinum C2 toxin increases endothelial permeability in vitro. J. Clin. Invest. 87:1575-1584.

12. Schnittler, H., A. Wilke, T. Gress, N. Suttorp, and D. Drenckhahn. 1990. Role of endothelial actin and myosin in the control of paracellular permeability. J. Physiol. (Lond.). 431:379-401.

13. Langeler, E. G., and V. W. M. Van Hinsbergh. 1991. Norepinephrine and iloprost improve barrier function of human endothelial cell monolayers: role of cAMP. Am. J. Physiol. 260:C1052-C1059.

14. Minnear, F. L., M. A. A. DeMichele, D. G. Moon, C. L. Rieder, and J. W. Fenton II. 1989. Isoproterenol reduces thrombin-induced pulmonary endothelial permeability in vitro. Am. J. Physiol. 257:H1613-H1623.

15. Stelzner, T. J., J. V. Weil, and R. F. O'Brien. 1989. Role of cyclic adenosine monophosphate in the induction of endothelial barrier properties. J. Cell. Physiol. 139:157-166.

16. Kobayashi, H., T. Kobayashi, and M. Fukushima. 1987. Effects of dibutyryl cAMP on pulmonary air embolism-induced lung injury in awake sheep. $J$. Appl. Physiol. 63:2201-2207.

17. Kennedy, T. P., J. R. Michael, J. R. Hoidal, D. Hasty, A. M. Sciuto, C. Hopkins, R. Lazar, G. K. Bysani, E. Tolley, and G. H. Gurtner. 1989. Dibutyryl cAMP, aminophylline, and $\beta$-adrenergic agonists protect against pulmonary edema caused by phosgene. J. Appl. Physiol. 67:2542-2552.

18. Carson, M. R., S. S. Shasby, and D. M. Shasby. 1989. Histamine and inositol phosphate accumulation in endothelium: cAMP and a G protein. Am. J. Physiol. 257:L259-L264.

19. Seifert, A. F., W. J. Thompson, A. Taylor, W. H. Wilborn, J. Barnard, and J. Haynes. 1992. Reversal of increased microvascular permeability associated with ischemia-reperfusion: role of cAMP. J. Appl. Physiol. 72:389-395.

20. Seamon, K. B., W. Padgett, and J. W. Daly. 1981. Forskolin: unique diterpene activator of adenylate cyclase in membranes and in intact cells. Proc. Natl. Acad. Sci. USA. 78:3363-3367.

21. Brotherton, A. F. A., D. E. Macfarlane, and J. C. Hoak. 1982. Prostacyclin biosynthesis in vascular endothelium is not inhibited by cyclic AMP: studies with 3-isobutyl-1-methylxanthine and forskolin. Thromb. Res. 28:637-647.

22. Beavo, J. A., and D. H. Reifsnyder. 1990. Primary sequence of cyclic nucleotide phosphodiesterase isoenzymes and the design of selective inhibitors. Trends Pharmacol. Sci. 11:150-155.

23. Schudt, C., S. Winder, B. Müller, and D. Ukena. 1991. Zardaverine as a selective inhibitor of phosphodiesterase isoenzymes. Biochem. Pharmacol. 42:153-162.

24. Schudt, C., S. Winder, S. Forderkunz, A. Hatzelmann, and V. Ullrich. 1991. Influence of selective phosphodiesterase inhibitors on human neutrophil functions and levels of cAMP and $\mathrm{Ca}^{2+}$. Naunyn-Schmiedeberg's Arch. Pharmacol. 344:682-690.

25. Souness, J. E., B. K. Diocee, W. Martin, and S. A. Moodie. 1990. Pig aortic endothelial-cell cyclic nucleotide phosphodiesterases. Biochem. J. 266:127-132.

26. Lugnier, C., and V. B. Schini. 1990. Characterization of cyclic nucleotide phosphodiesterases from cultured bovine aortic endothelial cells. Biochem. Pharmacol. 39:75-84.

27. Bhakdi, S., R. Füssle, and J. Tranum-Jensen. 1981. Staphylococcal alphatoxin: oligomerization of hydrophilic monomers to form amphiphilic hexamers induced through contact with deoxycholate detergent micelles. Proc. Natl. Acad. Sci. USA. 78:5475-5479.

28. Suttorp, N., W. Seeger, E. Dewein, S. Bhakdi, and L. Roka. 1985. Staphylococcal alpha-toxin induced $\mathrm{PGI}_{2}$ production in endothelial cells: role of calcium. Am. J. Physiol. 248:C127-C134.

29. Suttorp, N., C. Galanos, and H. Neuhof. 1987. Endotoxin alters arachidonate metabolism in endothelial cells. Am. J. Physiol. 253:C384-C390.

30. Suttorp, N., B. Flöer, H. Schnittler, W. Seeger, and S. Bhakdi. 1990. Effect of $E$. coli hemolysin on endothelial cell function. Infect. Immun. 58:3796-3801.

31. Beers, R. F., and I. W. Sizer. 1952. A spectrophotometric method for measuring the breakdown of hydrogen peroxide by catalase. J. Biol. Chem. 195:133-140

32. Dunn, O. J., and V. A. Clark. 1974. Applied Statistics: Analysis of Variance and Regression. John Wiley \& Sons, Inc., New York.

33. MacPhee, C. H., D. H. Reifsnyder, T. A. Moore, K. M. Lerea, and J. A. Beavo. 1988. Phosphorylation results in activation of a cAMP phosphodiesterase in human platelets. J. Biol. Chem. 263:10353-10358.

34. Grant, P. G., A. F. Mannarino, and R. W. Colman. 1988. cAMP mediated phosphorylation of the low -Km cAMP phosphodiesterase markedly stimulates its catalytic unit. Proc. Natl. Acad. Sci. USA. 85:9071-9075.

35. Shasby, D. M., S. E. Lind, S. S. Shasby, J. C. Goldsmith, and G. W. Hunninghake. 1985. Reversible oxidant-induced increases in albumin transfer across cultured endothelium: alterations in cell shape and calcium homeostasis. Blood. 65:605-614.

36. Holman, R. G., and R. V. Maier. 1990. Oxidant-induced endothelial leak correlates with decreased cellular energy levels. Am. Rev. Respir. Dis. 141:134140.

37. Barsony, J., and S. J. Marx. 1990. Immunocytology on microwave-fixed cells reveals rapid and agonist-specific changes in subcellular accumulation patterns for cAMP and CGMP. Proc. Natl. Acad. Sci. USA. 87:1188-1192.

38. Wilson, J., M. Winter, and D. M. Shasby. 1990. Oxidants, ATP depletion, and endothelial permeability to macromolecules. Blood. 76:2578-2582.

39. Varani, J., S. H. Phan, D. F. Gibbs, U. S. Ryan, and P. A. Ward. 1990 $\mathrm{H}_{2} \mathrm{O}_{2}$-mediated cytotoxicity of rat pulmonary endothelial cells: changes in adenosine triphosphate and purine products and effects of protective interventions. Lab. Invest. 63:683-689.

40. Gottlieb, A. I., B. L. Langille, M. K. K. Wong, and D. W. Kim. 1991. Structure and function of the endothelial cytoskeleton. Lab. Invest. 65:123-137.

41. Kamm, K. E., and J. T. Stull. 1989. Regulation of smooth muscle contractile elements by second messengers. Ann. Rev. Physiol. 51:299-313.

42. Rasmussen, H., G. Kelley, and J. S. Douglas. 1990. Interactions between $\mathrm{Ca}^{2+}$ and cAMP messenger system in regulation of airway smooth muscle contraction. Am. J. Physiol. 258:L279-L288. 